\title{
Identification of Polymorphisms of Fas Gene and Association Analysis in Hanwoo
}

\author{
Seung-Chang Kim ${ }^{1}$, Seung-Hwan Lee ${ }^{1}$, Bum-Soo Kim ${ }^{1}$, Tae-Hun Kim ${ }^{1}$, Hwan-Hoo Seong ${ }^{1}$, Sung-Jong Oh ${ }^{1}$, Du-Hak Yoon ${ }^{2}$ \\ and Bong-Hwan $\mathrm{Choi}^{1 *}$ \\ ${ }^{1}$ Division of Animal Genomics \& Bioinformatics, National Institute of Animal Science, RDA, Suwon, 441-706, Korea, \\ ${ }^{2}$ Department of Animal Science, Kyungpook National University, Sangju, 742-170, Korea
}

\begin{abstract}
Fas gene known to associate with intramuscular fat content in Korean cattle was selected for DNA marker development. Fas (APO-1, CD95), a member of the tumor necrosis factor (TNF) receptor superfamily, is a cell membrane protein that mediates apoptosis (programmed cell death). We discovered single nucleotide polymorphisms (SNPs) within Fas gene in order to develop novel DNA markers at genomic level. Of this gene to search for SNP, sequences of whole exon and $1 \mathrm{~kb}$ range of both front and back of the gene using 24 cattle were determined by direct-sequencing methods. As a result, 16 SNPs in exon, 37 SNPs in intron and 2 SNPs in promoter region, a total of 55 SNPs were discovered. In these SNPs, thirty-one common polymorphic sites were selected considering their allele frequencies, haplotype-tagging status and Linkage Disequilibrium(LD) for genotyping in larger-scale subjects. Selected SNPs were confirmed genotype through SNaPshot method $(n=274)$ and were examined for possible genetic association of Fas polymorphisms with carcass weight (CWT), eye muscle area (EMA), and backfat thickness (BF). So, the SNP have been identified significant g.- $12 \mathrm{~T}>\mathrm{G}$, g.1112T $>\mathrm{G}$ and g.32548T $>\mathrm{C}$. These results suggest that polymorphism of Fas gene was associated with meat quality traits in Hanwoo.
\end{abstract}

(Key words : Fas, Hanwoo, Linkage disequilibrium, Single nucleotide polymorphism)

\section{INTRODUCTION}

Improvement of livestock through the selection of superior cattle has been progressing and many studies conducted to detect Quantitative trait loci (QTL) associated economic traits. So, estimate is made by breeding value of livestock using DNA marker. This approach was selected DNA marker related to phenotype based on genetic value and statistical significance through association analysis between genetic variation and phenotype after identification of the genetic variation structure at each object. Then, the DNA marker has been used to the Maker-Assisted Selection (MAS) (Darvasi and Soller, 1994, Lande and Thompson, 1990).

To date, genomic studies for phenotypic profiling involving the use of quantitative trait loci (QTL) have identified genes associated with economic traits in beef. In particular, to identify genetic markers for traits, single nucleotide polymorphism (SNP) discovery and traits relevant studies at target gene has been going on.

A cell-surface protein Fas (APO-1, CD95), was first recognized as an apoptosis inducer when activated human lymphocytes and certain cell lines underwent apoptosis upon exposure to monoclonal anti-Fas antibodies (Trauth, et al., 1989, Yonehara, et al., 1989). Molecular cloning of human and mouse Fas (hFas and mFas) cDNAs (Itoh, et al., 1991, Oehm, et al., 1992, Watanabe-Fukunaga, et al., 1992) demonstrated that it belongs to the tumor necrosis factor receptor (TNFR) superfamily, which includes the low-affinity nerve growth factor receptor (NGFR), tumor necrosis factor receptor (TNFR) types I and II, human B-cell antigen CD40, T-cell antigen CD27, and OX40 (Camerini, et al., 1991, Johnson, et al., 1986, Loetscher, et al., 1990, Mallett, et al., 1990, Schall, et al., 1990, Stamenkovic, et al., 1989).

Our previous study found that Fas was negatively correlated to intramuscular fat content in the $m$. longissimus tissue of Korean cattle. HSPB1 expression in both mRNA and protein was shown to be negatively related to intramuscular fat content (Kim, et al., 2011). TNF receptor superfamily member 6 (FAS) and angiotensinogen (AGT), were regulators of the HSPB1 gene. These findings suggest that the Fas

* Corresponding author: Dr Bong-Hwan Choi, National Institute of Animal Science, RDA, Suwon, 441-706 Korea. Tel: 031-290-1592, Fax: 031-290-1792, E-mail: bhchoi@korea.kr 
gene may be one of the 258 key genes controlling adipogenesis through a MAPK signaling pathway. According to these results, Fas protein play an important role in the trait expression associated with fat synthesis.

Therefore, the objective of this study was to discover single nucleotide polymorphism through determining nucleotide sequences of the Fas gene located within QTL regions related to meat quality trait and to identify association with each SNP and economic traits in Hanwoo.

\section{MATERIALS AND METHODS}

\section{Animals and phenotypes}

Phenotype data and blood samples for SNP marker genotyping were obtained from 274 steers descending from 76 sires and unrelated dams from National Institute of Animal Science. The Hanwoo received a total mixed diet of concentrate and rice straw with a ratio in total feed of about 1.5:1, 2:1 and 4.5:1 for growing period (4-12 months), finishing period I (13-18 months) and finishing period II (19-24 months), respectively for ad libitum intake. Crude protein $(\mathrm{CP})$ and total digestible nutrients (TDN) of the concentrate were $14-16,11-13$ and $11 \%$ and $68 \sim 70 \%, 71 \sim$ $73 \%$ and $72 \sim 73 \%$ for growing period, finishing period I and finishing period II, respectively. Phenotypic data in this study included carcass weight(CWT), longissimus muscle area (LMA), back fat thickness (BF) and marbling score (MAR). $\mathrm{BF}$, eye muscle area (EMA) and MAR were measured at the $12^{\text {th }}-13^{\text {th }}$ rib junction after a 24 hour chill. The statistics for phenotypic data is summarized in Table 1. Marbling score was assessed on 1 to 7 scales, and the degree of marbling was evaluated based on the Korean Beef Marbling Standard (BMS) from Animal product Grading Service in Korea (APGS, 1995).

\section{Genomic DNA}

Genomic DNA was separated from blood of cattle following modified salting out method (Miller, et al., 1988). DNA was quantified using the NanoDrop ND-1000 Spectrophotometer (NanoDrop Technology). DNA samples were diluted to $10 \mathrm{ng} / \mathrm{\mu l}$ using double distilled water and stored at $-20^{\circ} \mathrm{C}$.

\section{Sequencing and SNP analysis}

SNP identification in Fas gene was used for 24 different beef having the different grandsire and sire. Primer for the sequence determination was produced to be about $700 \mathrm{bp}$ of PCR product using primer3 software (http://www-genome. wi.mit.edu/cgi-bin/primer3-www.results.cgiv) based on genetic information (BC140650.1) registered in the NCBI GenBank (Table 1). Polymerase chain reaction (PCR) was performed in $20 \mu \mathrm{l}$ volumes, each containing $50 \mathrm{ng}$ of genomic DNA, $2 \mu \mathrm{l}$ of $10 \mathrm{X}$ buffer $(100 \mathrm{mM}$ Tris $\mathrm{pH} 8.9,50 \mathrm{mM} \mathrm{KCl}, 15 \mathrm{mM}$ $\mathrm{MgCl}, 0.01 \%$ gelatin, $0.1 \%$ Triton $\mathrm{X}-100,10 \mathrm{mg} / \mathrm{ml}$ bovine serum albumin), $0.5 \mu \mathrm{l}$ of each primer (10 pmol), $1 \mu \mathrm{l}$ of dNTPs $(20 \mathrm{mM})$ and 0.5 unit of Hot Start Taq DNA polymerase (GeNet Bio, Korea). PCR conditions were $94^{\circ} \mathrm{C}$ for $5 \mathrm{~min}$ and 35 cycles of $30 \mathrm{sec}$ at $94^{\circ} \mathrm{C}, 30 \mathrm{sec}$ at $60^{\circ} \mathrm{C}$, $1 \mathrm{~min}$ at $72^{\circ} \mathrm{C}$, and a final step of $10 \mathrm{~min}$ at $72^{\circ} \mathrm{C}$ using a Tetrad 2 Peltier Thermal Cycler(Bio-Rad, USA). PCR product identified on $1.5 \%$ agarose gel was filtered by MultiScreen filter plates (Millipore, Ireland). Then PCR was performed in $10 \mu \mathrm{l}$ volumes, each containing $2 \mu \mathrm{l}$ of Filtered PCR product, $1.75 \mu \mathrm{l}$ of $5 \mathrm{X}$ buffer $(400 \mathrm{mM}$ tris, $10 \mathrm{mM}$ $\left.\mathrm{MgCl}_{2}\right), 0.5 \mu \mathrm{l}$ of Big Dye and $1 \mu \mathrm{l}$ of each primer (5 pmol). PCR conditions were $96^{\circ} \mathrm{C}$ for $10 \mathrm{sec}$ and 34 cycles of 5 sec at $50^{\circ} \mathrm{C}, 4 \mathrm{~min}$ at $60^{\circ} \mathrm{C}$. PCR product was refined using alcohol after PCR and dried. Dried sample was added with $8 \mu \mathrm{l}$ of $\mathrm{Hi}-\mathrm{Di}^{\mathrm{TM}}$ Formamide and allowed to react for $2 \mathrm{~min}$ at $95^{\circ} \mathrm{C}$. Then, DNA sequence was analyzed on $\mathrm{ABI}$ 3730XL Genetic Analyzer (Applied Biosystems, USA). SNP was analyzed by the Lasergene SeqMAN software (version 7, DNA Star, USA).

\section{SNaPshot and genotyping}

Table 1. SNaPshot probes for the detection of Fas genotypes

\begin{tabular}{ccccc}
\hline Probe & Sequence $\left(5^{\prime}{ }^{\prime}>3^{\prime}\right)$ & Position & SNP & Size(bp) \\
\hline \hline SNP1 & at $_{(11)}$ CCGGGGACATTTCTTTAGGTCTTTTCAAA & g.-12 & T $>$ G & 51 \\
SNP2 & at $_{(10)}$ AAGCCTAAGCCGCATCCACCTCTTT & g.1112 & T $>$ G & 45 \\
SNP3 & $\operatorname{ta}_{(4)}$ tCTGGTGAGAGTAAATACCCATGTTCATC & g.32548 & T $>$ C & 37 \\
\hline
\end{tabular}


SNaPshot probes were manually designed by checking their annealing temperature (Table 1). The length of a primer was modified by the addition of non-homologous polynucleotides at the $5^{\prime}$ end. The primers for PCR and SNaPshot analysis were synthesized by Bioneers (Daejeon, Korea). The SNaPshot reaction was performed in a total volume of $5 \mu \mathrm{l}$ using $2 \mu \mathrm{l}$ of SNaPshot Mastermix, $2 \mu \mathrm{l}$ of primer and $1 \mu \mathrm{l}$ of filtered PCR product. Thermal cycling conditions were 25 cycles of $10 \mathrm{~s}$ at $96^{\circ} \mathrm{C}, 5 \mathrm{~s}$ at $55^{\circ} \mathrm{C}$ and $30 \mathrm{~s}$ at $60^{\circ} \mathrm{C}$. The $\mathrm{SNaPshot}$ products were then cleaned by adding $1 \mu \mathrm{l}$ of SAP and $1 \mathrm{hr}$ incubation at $37^{\circ} \mathrm{C}$, followed by a $15 \mathrm{~min}$ enzyme denaturation at $75^{\circ} \mathrm{C}$. Fragments were separated on an ABI 3730-Genetic Analyzer (Applied Biosystems, Foster City, CA, USA) using $8.5 \mu$ l of formamide, $0.5 \mu \mathrm{l}$ of GeneScan ${ }^{\mathrm{TM}}-120$ LIZ $^{\mathrm{TM}}$ size standard (Applied Biosystems) and $1 \mu$ of cleaned SNaPshot product. A 36 $\mathrm{cm}$ capillary array and the polymer POP-4 were used andthe instrument settings were defaulted as recommended by the manufacturer. Raw data was analyzed using the SeqMAN software. Main data analysis was accomplished with a PHASE v2.1.1 and Haploxt.

\section{Statistical analyses}

Analysis of the statistical relevance with the phenotypic measurement and the 3 SNP genotype of Fas gene were evaluated with the mixed regression models using ASReml 3.0 program(Gilmour, et al., 2006). Also, p-value less than 0.01 were accepted as statistically significant. The difference of mean value was performed a test of significance of difference of genotype through a Fisher's least significant difference test using the following statistical linear model:

$$
Y_{i j k}=\mu+Y S_{i}+b \cdot D_{i j k}+\text { Genotype }_{j}+A_{i j k}+e_{i j k}
$$

where $Y_{i j k}$ is the observation of the carcass traits, $\mu$ is the overall mean for each trait, $Y S_{i}$ is the effect of season, $b$ is convariation of slaughter age, $D_{i j k}$ is slaughter age (month), Genotype $_{j}$ is the effect of genotype, $A_{i j k}$ is the fixed effect of individual and $e_{i j k}$ is the random residual effect.

\section{RESULTS \& DISCUSSION}

Fas gene have 9 exons and located at 11241196 11275050 bp in bovine chromosome 26 (BTA26). To search for SNP of this gene, sequences of whole exon and $1 \mathrm{~kb}$ range of both front and back of the gene were determined by PCR and PCR-direct sequencing using 24 different cattle having each different grandsire and sire. The results showed homology more than $99 \%$ with sequence reported in GenBank (BC140650.1). The SNP was selected locus having mutation frequency of 0.01 or more and nucleotide both homo- and hetero-type.

As a result, 16 SNPs in exon, 37 SNPs in intron and 2 SNPs in promoter region, a total of 55 SNPs were discovered. Also, 3 non-synonymous SNP in 3 exons found respectively. In these SNPs, thirty-one common polymorphic sites were selected considering their allele frequencies, haplotype-tagging status and Linkage Disequilibrium(LD) for genotyping in larger-scale subjects. Selected SNPs were confirmed genotype through SNaPshot method using population of 34 and 35 progeny test cattle and were examined for possible genetic association of Fas polymorphisms with CWT, EMA and BF. So, the SNP in promoter region, in intron I region and in exon IX region have been identified (Fig. 1). Identified three SNP has been verified as the new SNP as a result compared with the SNP database of GenBank.

Association analysis of carcass traits and SNP utilized 274 cattle for progeny test having carcass traits recorded and carcass traits of the testing material used in the analysis are shown in Table 2. Association analysis of SNP in Fas gene with carcass traits was used in Generalized Linear Model (GLM). As a result, single locus association analysis for Fas gene showed that $3 \mathrm{SNP}$ were associated with at least 1 meat quality trait. The g. $-12 \mathrm{~T}>\mathrm{G}$ was found to be significant $(\mathrm{P}<0.01)$ with BF, G.1112T $>\mathrm{G}$ with $\operatorname{EMA}(\mathrm{P}<0.001)$ and G.32548T $>$ C with EMA and $\operatorname{CWT}(\mathrm{P}<0.01)$ (Table 3). In case of g. $-12 \mathrm{~T}>\mathrm{G}$ SNP identified significant association, the

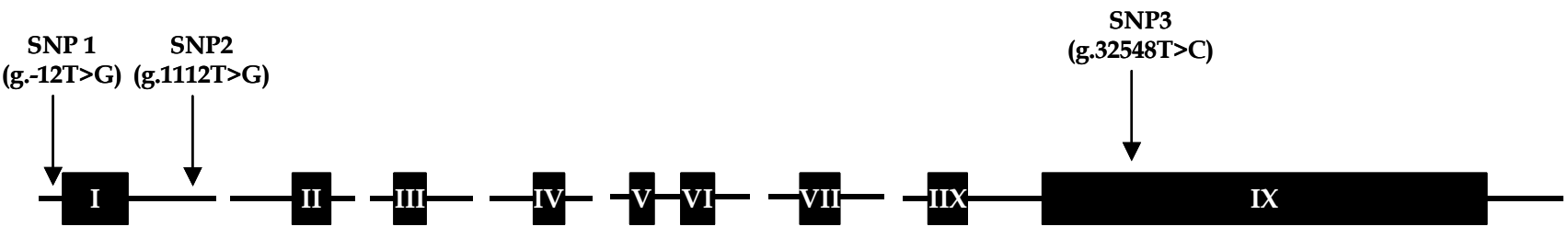

Fig. 1. The positions of detected SNPs at Tumor necrosis factor receptor superfamily member 6 (Fas) gene in Korean cattle (Hanwoo). 
Table 2. Means, standard deviation (SD) and extreme value of the phenotypes measured on carcass traits in Hanwoo

\begin{tabular}{ccccc}
\hline Traits & Mean & SD & Minimum & Maximum \\
\hline \hline CWT $(\mathrm{kg})$ & 321.74 & 34.45 & 174 & 423 \\
EMA $\left(\mathrm{cm}^{2}\right)$ & 58.89 & 8.57 & 30 & 99 \\
BF $(\mathrm{cm})$ & 8.16 & 3.04 & 3 & 21 \\
\hline
\end{tabular}

CWT, carcass weight; EMA, eye muscle area; BF, backfat thickness.

Table 3. Least square means and standard errors of phenotypic measurements from carcass traits by Fas genotypes in Hanwoo

\begin{tabular}{|c|c|c|c|c|c|}
\hline Trait & Type & & Genotype & & $P$ value \\
\hline \multirow{2}{*}{$\mathrm{BF}$} & \multirow{2}{*}{ g. $-12 \mathrm{~T}>\mathrm{G}$} & TT & GT & GG & \multirow{2}{*}{$\mathrm{P}<0.01 * *$} \\
\hline & & $8.09 \pm 0.35$ & $8.64 \pm 0.31$ & $6.92 \pm 0.46$ & \\
\hline \multirow{4}{*}{ EMA } & \multirow{2}{*}{ g. $1112 \mathrm{~T}>\mathrm{G}$} & GG & GT & TT & \multirow{2}{*}{$\mathrm{P}<0.001 * * *$} \\
\hline & & $71.05 \pm 6.48$ & $70.64 \pm 2.44$ & $69.86 \pm 3.5$ & \\
\hline & \multirow{2}{*}{ g. $32548 \mathrm{~T}>\mathrm{C}$} & $\mathrm{CC}$ & CT & TT & \multirow{2}{*}{$\mathrm{P}<0.01 * *$} \\
\hline & & $77.98 \pm 3.86$ & $62.75 \pm 4.76$ & $70.82 \pm 2.95$ & \\
\hline \multirow{2}{*}{ CWT } & \multirow{2}{*}{ g. $32548 \mathrm{~T}>\mathrm{C}$} & $\mathrm{CC}$ & CT & TT & \multirow{2}{*}{$\mathrm{P}<0.01 * *$} \\
\hline & & $343.43 \pm 4.98$ & $308.67 \pm 3.56$ & $303.69 \pm 11.4$ & \\
\hline
\end{tabular}

BF, backfat thickness; EMA, eye muscle area; CWT, carcass weight.

GT and TT genotypes was shown to be superior to the more than GG genotype in BF. Similarly, g.1112T $>$ G was shown to be superior to the GG and GT genotypes more than TT genotype in EMA. But at locus g.32548T $>C$, Hanwoo with genotype CC had higher EMA and CWT than the one with genotypes CT and TT.

Because promoter is a region of DNA that facilitates the transcription of a particular gene, SNP of promoter region was assumed to play an important role in phenotypic traits. The nucleotide variation of a particular location affects relatively low the expression of genes when SNP of intron region compared with it of exon region. But in some cases, SNP of intron in specific genes play an important role in transcription and translation (Nott, et al., 2003).

Chromosomes known to exon region meat quality trait QTL such as BTA14 and BTA26 are primary sites for the presence of functionally important genes affecting lipid metabolism (Casas, et al., 2004, Marques, et al., 2009). SNP of many genes that exist in the BTA26 QTL region and the association study of economic traits have been reported. Among important genes on BTA26, there is the fibroblast growth factor 8 (FGF8). Because of its consistent links to obesity QTL in mice, it was suggested that it might act as a master regulator or interacting element controlling multiple genes that contribute to adiposity in mice (Stylianou, et al., 2006). Economic traits due to SNP variation of Fas gene appeared in the experiment are not yet confirmed whether they have a direct effect or not. They have been shown to SNP (promoter, intron and synonymous) that do not regulate the function of the gene. So, it could be LD effect with lipid metabolism-related genes associated with the QTL of each trait around Fas gene. However, previous study reported that Fas gene was negatively correlated to intramuscular fat content (Kim, et al., 2011). So, Fas gene was thought to have association with economic traits. Therefore, it is thought to be very high as LD marker associated with the QTL of each trait potentially.

The final goal of this research is to find information about molecular markers that could be utilized in marker assisted selection. The identification of the causative mutations accounting for the largest amount of variability for these traits would not only allow for increased accuracy of 
selection but would also allow for focused genotyping of markers essential for selection of a specific trait. Thus, continued evaluation of this region and the markers contained within, must be further evaluated prior to being implemented into a marker assisted selection.

As a result of this study, bovine Fas genes existing on BTA26 region appeared to be related to BF, EMA and CWT in Hanwoo. Currently, the meat quality grade in beef grading uses the BF, EMA and CWT as basis and these are traits have significant impactin grading the cattle carcass. Therefore, the Fas gene was considered what could be used to the improvement and the selection of Hanwoo.

\section{ACKNOWLEDGEMENTS}

This work was supported by the "Integrated bovine genome DB construction and detection of quantitative traits loci for production of cattle" project of the National Institute of Animal Science, RDA, Korea.

\section{REFERENCES}

APGS. 1995. Report of business for animal products grading. Animal products grading system, National Co-operatives Federation, Korea.

Camerini, D., Walz, G., Loenen, W. A., Borst, J. and Seed, B. 1991. The $\mathrm{T}$ cell activation antigen CD27 is a member of the nerve growth factor/tumor necrosis factor receptor gene family. J Immunol. 147:3165-9.

Casas, E., Keele, J. W., Shackelford, S. D., Koohmaraie, M. and Stone, R. T. 2004. Identification of quantitative trait loci for growth and carcass composition in cattle. Anim. Genet. 35:2-6.

Darvasi, A. and Soller, M. 1994. Selective DNA pooling for determination of linkage between a molecular marker and a quantitative trait locus. Genetics. 138:1365-73.

Gilmour, A. R., Gogel, B. J., Cullis, B. R. and Thompson, R. 2006. ASREML User Guide Release 2.0. VSN International Ltd., Hempstead, HP1 1ES, UK.

Itoh, N., Yonehara, S., Ishii, A., Yonehara, M., Mizushima, S., Sameshima, M., Hase, A., Seto, Y. and Nagata, S. 1991. The polypeptide encoded by the cDNA for human cell surface antigen Fas can mediate apoptosis. Cell. 66:233-43.

Johnson, D., Lanahan, A., Buck, C. R., Sehgal, A., Morgan, C., Mercer, E., Bothwell, M. and Chao, M. 1986. Expression and structure of the human NGF receptor. Cell. 47:545-54.

Kim, N. K., Lim, D., Lee, S. H., Cho, Y. M., Park, E. W., Lee,
C. S., Shin, B. S., Kim, T. H. and Yoon, D. 2011. Heat shock protein b1 and its regulator genes are negatively correlated with intramuscular fat content in the longissimus thoracis muscle of hanwoo (korean cattle) steers. J. Agric. Food Chem. 59:5657-64.

Lande, R. and Thompson, R. 1990. Efficiency of Marker-Assisted Selection in the Improvement of Quantitative Traits. Genetics. 124:743-756.

Loetscher, H., Pan, Y. C., Lahm, H. W., Gentz, R., Brockhaus, M., Tabuchi, H. and Lesslauer, W. 1990. Molecular cloning and expression of the human $55 \mathrm{kd}$ tumor necrosis factor receptor. Cell. 61:351-9.

Mallett, S., Fossum, S. and Barclay, A. N. 1990. Characterization of the MRC OX40 antigen of activated CD4 positive $\mathrm{T}$ lymphocytes--a molecule related to nerve growth factor receptor. EMBO J. 9:1063-8.

Marques, E., Nkrumah, J. D., Sherman, E. L. and Moore, S. S. 2009. Polymorphisms in positional candidate genes on BTA14 and BTA26 affect carcass quality in beef cattle. J. Anim. Sci. 87:2475-84.

Miller, S. A., Dykes, D. D. and Polesky, H. F. 1988. A simple salting out procedure for extracting DNA from human nucleated cells. Nucleic Acids Res. 16:1215.

Nott, A., Meislin, S. H. and Moore, M. J. 2003. A quantitative analysis of intron effects on mammalian gene expression. RNA. 9:607-17.

Oehm, A., Behrmann, I., Falk, W., Pawlita, M., Maier, G., Klas, C., Li-Weber, M., Richards, S., Dhein, J. and Trauth, B. C. 1992. Purification and molecular cloning of the APO-1 cell surface antigen, a member of the tumor necrosis factor/nerve growth factor receptor superfamily. Sequence identity with the Fas antigen. J. Biol. Chem. 267:10709-15.

Schall, T. J., Lewis, M., Koller, K. J., Lee, A., Rice, G. C., Wong, G. H., Gatanaga, T., Granger, G. A., Lentz, R. and Raab, H. 1990. Molecular cloning and expression of a receptor for human tumor necrosis factor. Cell. 61:361-370.

Stamenkovic, I., Clark, E. A. and Seed, B. 1989. A B-lymphocyte activation molecule related to the nerve growth factor receptor and induced by cytokines in carcinomas. EMBO J. 8:1403-10.

Stylianou, I., Korstanje, R., Li, R., Sheehan, S., Paigen, B. and Churchill, G. 2006. Quantitative trait locus analysis for obesity reveals multiple networks of interacting loci. Mamm. Genome 17:22-36.

Trauth, B. C., Klas, C., Peters, A. M., Matzku, S., Moller, P., Falk, W., Debatin, K. M. and Krammer, P. H. 1989. Monoclonal antibody-mediated tumor regression by induction 
of apoptosis. Science. 245:301-5.

Watanabe-Fukunaga, R., Brannan, C. I., Itoh, N., Yonehara, S., Copeland, N. G., Jenkins, N. A. and Nagata, S. 1992. The cDNA structure, expression, and chromosomal assignment of the mouse Fas antigen. J Immunol. 148:1274-9.

Yonehara, S., Ishii, A. and Yonehara, M. 1989. A cell-killing monoclonal antibody (anti-Fas) to a cell surface antigen codownregulated with the receptor of tumor necrosis factor. J. Exp. Med. 169:1747-56.

(Received Nov. 30, 2011; Revised Dec. 16, 2011; Accepted Dec. 19, 2011) 